\title{
Development of Magnetic Separator for Biomaterials Labeled by Magnetic Beads
}

\author{
W. Maeda, S. Yamada*, and M. Iwahara \\ Graduate School of Natural Science and Technology, Kanazawa Univ., Kakuma-machi, Kanazawa, Ishikawa 920-1192, Japan \\ *Division of Biological Measurement and Applications, Institute of Nature and Environmental Technology, Kanazawa Univ., Kakuma-machi, \\ Kanazawa, Ishikawa 920-1192, Japan
}

\begin{abstract}
Magnetic separation is an important method of purifying of cells or DNA. A properly designed magnetic separator causes less physical and chemical damage to a target and has a high separation rate. This paper presents a new high-throughput continuous magnetic separator for biomaterials labeled by magnetic beads. The separator consists of three rectangular coils, two circular coils, and a separation chamber. These instruments were designed by a numerically analyzing of the magnetic field and the movement of magnetic beads. A separation rate over $90 \%$ was obtained with this system in a separation test using magnetic beads.
\end{abstract}

Key words: magnetic separation, magnetic beads, gradient magnetic field, biomaterial

\section{磁気ビーズによる生体物質分離用磁気分離装置の開発に関する検討 \\ 前田 航, 山田外史 *, 岩原正吉 \\ 金沢大学大学院 自然科学研究科, 石川県金沢市角間町（广920-1192） \\ *金沢大学 自然計測応用研究センター人間計測制御研究部門, 石川県金沢市角間町 (T920-1192)}

\section{1 はじめに}

細胞や生体関連物質の分離技術は，細胞分析等の分野におい て必須の技術であり，近年注目されている再生医療の分野にお いても種々の臓器に分化可能な間葉系幹細胞を骨髄中から取 り出す必要があるなど, 分離技術は重要性を増している. 従来 からこれらの分野での分離技術としては, 密度差を用いた遠心 分離や光学的特性を用いた FACSs(Fluorescence Activated Cell Sorters) が用いられて来たが, 近年では磁気ラベリング技術の 急速な進展に伴い, 簡易な装置で物理的・化学的に低ダメージ の分離を行うことができる磁気分離技術も広く用いられるに 至っている ${ }^{1,2)}$.

磁気分離では，直径 1 5 $\mu \mathrm{m}$ の鉄酸化物を含んだポリスチレ ン製のビーズに分離対象物を抗原抗体反応により選択的に結合 させ，それらを磁力で回収することで分離を行う。磁力による 回収過程では, 従来から分離容器を用いたバッチ処理的な方法 が用いられて来たが, 分離工程の自動化の要求に応えるため, 流量 $1 \mu \mathrm{l} / \mathrm{min}$ 程度で連続的に分離を行える装置が開発されて きた ${ }^{3-5)}$. 本稿では現状で開発されている装置と比較して高ス ループットを実現する磁気分離装置を設計・試作し, 磁気ビー ズによる予備分離実験を行ったので報告する.

\section{2 磁気分離装置の動作原理}

本稿で提案する磁気分離装置の概要図を Fig. 1 に示す。この 装置は, 3 個の長方形コイルと 2 個の円形コイルと円形コイル の間に配置された分離容器から成る。磁気ビーズと結合された 分離対象物は, 分離容器 (Fig. 2) の Inlet から容器内に注入さ れ, 容器内を移動する間, コイルによる傾斜磁界に曝される. 磁気ビーズには傾斜磁界による磁力が働くため, 磁気ビーズと 分離対象物は $x$ 軸正方向に移動する。同時にこれらは水に押し
流されながら $y$ 軸正方向に移動，及び $z$ 軸負方向に沈殿してい き，最終的に Positive selectionに到達し，分離が達成される。

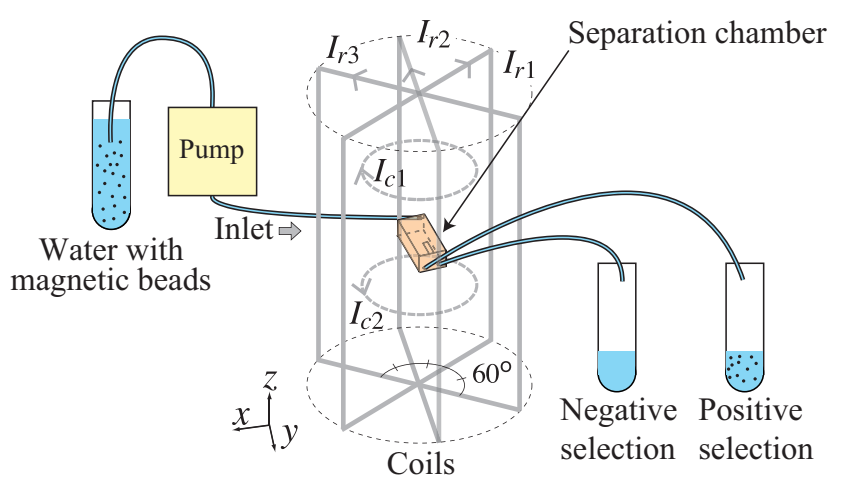

Fig. 1 Schematic of our magnetic separator.

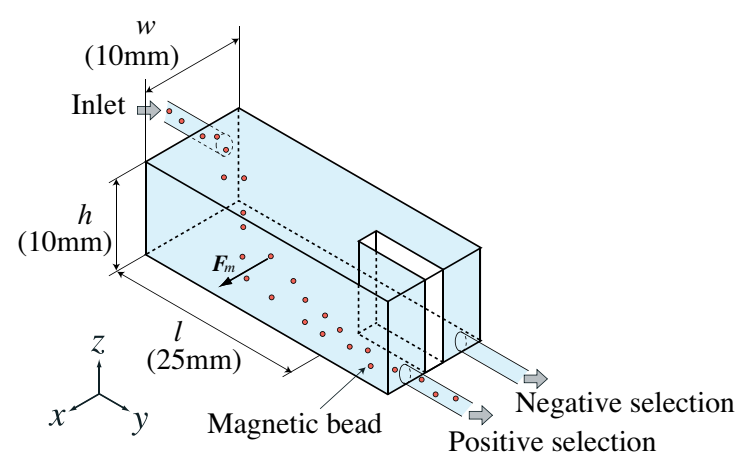

Fig. 2 More detailed schematic of the separation chamber. 

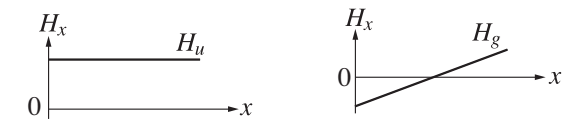

(a) $\mathrm{X}$-axis uniform magnetic (b) $\mathrm{X}$-axis positive gradient field $H_{u}$, along x-axis. magnetic field $H_{g}$ along x-axis.

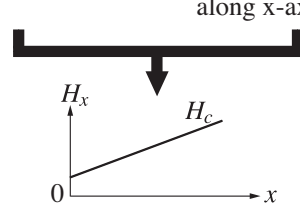

(c) X-axis magnetic field $H_{c}$, which has positive strength and positive gradient along $\mathrm{X}$-axis.

Fig. 3 Gradient magnetic fields for magnetic separation.

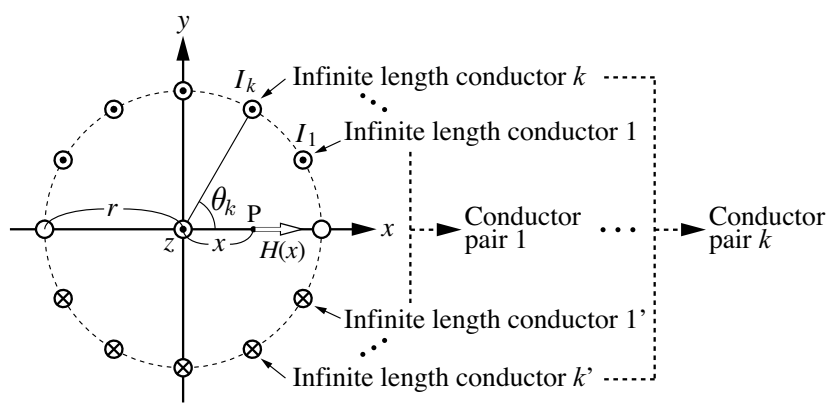

Fig. 4 Arrangement of infinite length conductors for generating uniform magnetic field.

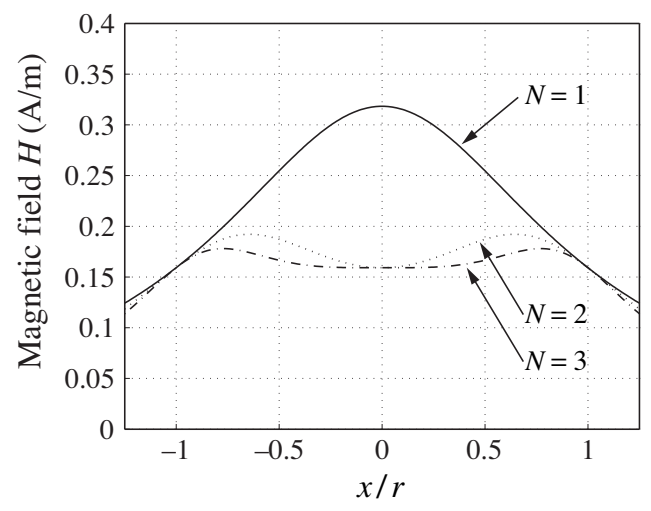

Fig. 5 Uniform magnetic field generated by infinite length conductors.

\section{3 分離装置各部の設計}

\section{1 傾斜磁界を発生させるためのコイル寸法の検討}

磁気ビーズに磁力を発生させるための傾斜磁界は, Fig. 3(a), (b) に示す均一磁界 $H_{u}$ と傾斜磁界 $H_{g}$ を合成することにより発 生させる。このように磁界を合成する理由は, 磁力は磁界強度 と磁界傾斜の積に比例することを考慮し, 強い磁力が得られる 領域をできるだけ広くするためである.

これらの均一及び傾斜磁界を発生させるベクトル・ポテン シャル $\boldsymbol{A}_{u}, \boldsymbol{A}_{g}$ は, 以下のように与えられる ${ }^{6)}$.

$$
\begin{gathered}
\boldsymbol{A}_{u}=\left(A_{x}, A_{y}, A_{z}\right)=(0,0, \alpha y) \\
\boldsymbol{A}_{g}=\left(A_{x}, A_{y}, A_{z}\right)=(\alpha y z,-\alpha x z, 0)
\end{gathered}
$$

Rectangular coil 2

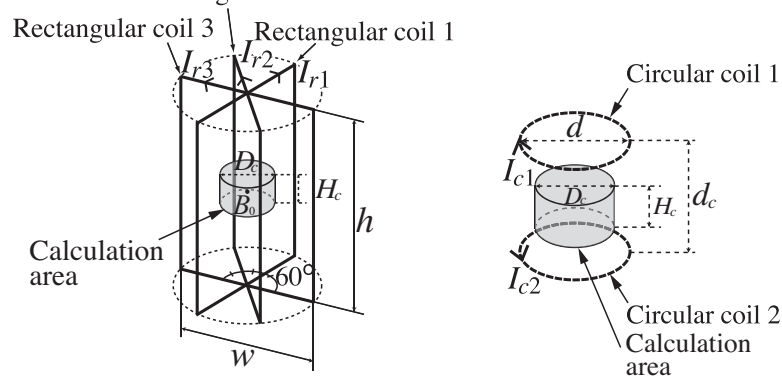

(a) Rectangular coils.

(b) Circular coils.

Fig. 6 Area of calculation for determining coil dimensions.

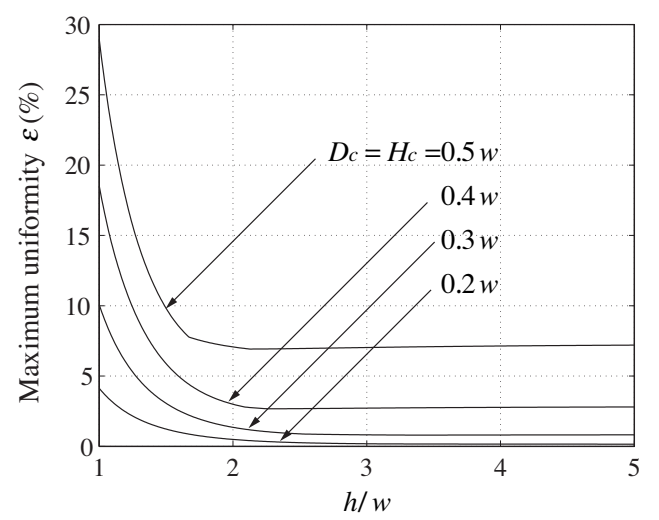

Fig. 7 Maximum magnetic field uniformity $\varepsilon$ at each ratio of height and width of rectangular coils $(h / w)$.

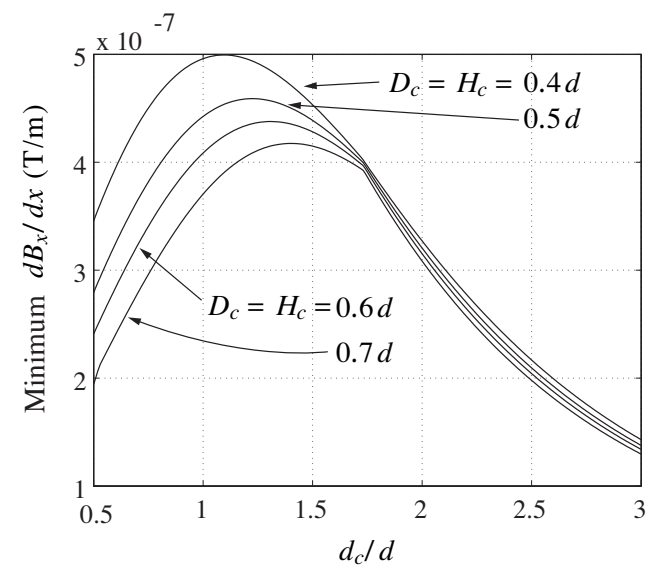

Fig. 8 Minimum magnetic field gradient $d B_{x} / d x$ at each ratio of interval $d_{c}$ and diameter $d$ circular coils $\left(d_{c} / d\right)$.

ここで， $\alpha$ は任意の定数である，一般にベクトル・ポテンシャ ル $\boldsymbol{A}$ と電流 $\boldsymbol{i}$ の間には以下のような関係がある.

$$
\boldsymbol{A}=\frac{\mu_{0}}{4 \pi} \int_{v} \frac{\boldsymbol{i}}{r} d v
$$

ここで, $r$ は $d v$ と $\boldsymbol{A}$ の間の距離である.上式からべクトル・ ポテンシャルと電流の方向は等しいので, 各ベクトル・ポテン シャルに対応する電流分布 $\boldsymbol{i}_{u}, \boldsymbol{i}_{g}$ は円筒座標系で表すと次式の ようになる。 
Table 1 Coil dimensions and number of turns.

\begin{tabular}{l|c|l|c}
\hline $\begin{array}{l}\text { Width of rectangular } \\
\text { coils }\end{array}$ & $8 \mathrm{~cm}$ & $\begin{array}{l}\text { Height of rectangu- } \\
\text { lar coils }\end{array}$ & $16 \mathrm{~cm}$ \\
\hline $\begin{array}{l}\text { Diameter of circular } \\
\text { coils }\end{array}$ & $4 \mathrm{~cm}$ & $\begin{array}{l}\text { Interval between cir- } \\
\text { cular coils }\end{array}$ & $4.4 \mathrm{~cm}$ \\
\hline Number of turns & 140 & & \\
\hline
\end{tabular}

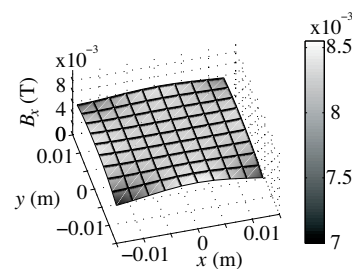

(a) Uniform magnetic field generated by rectangular coils

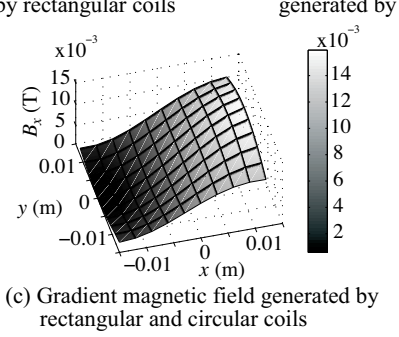

Fig. 9 Calculated magnetic field for all coils.

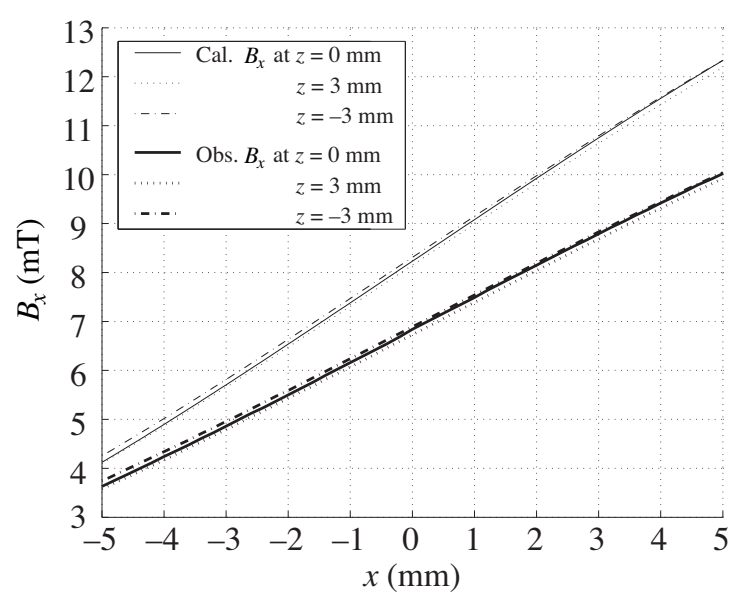

Fig. 10 Calculated and observed magnetic field of coils at $y=0$.

$$
\begin{gathered}
\boldsymbol{i}_{\boldsymbol{u}}=\left(i_{r}, i_{\theta}, i_{z}\right)=(0,0, \beta r \sin \theta) \\
\boldsymbol{i}_{\boldsymbol{g}}=\left(i_{r}, i_{\theta}, i_{z}\right)=(0,-\beta r z, 0)
\end{gathered}
$$

ここで, $\beta$ は定数である.

式 (4) の電流分布が満たされるとき, 半径 $r$ の円筒内におい て $x$ 方向均一磁界が発生する。この電流分布は, 複数の長方形 コイルを用いて近似的に発生させる.

磁界の均一性が確保される長方形コイル数を決定するため に, まず, 長方形コイルの短辺部分の導体を無視した Fig. 4 の ような $z$ 方向無限長導体による磁界を検討する。ここでは， $y$ 軸対称の位置にある 2 導体は, それぞれ導体ペアとして取り扱 うこととし， $k$ 番目の導体ペアの電流強度は式 (4) に基づき,
以下のように定める。

$$
I_{k}=\frac{I}{N} \sin \theta_{k}=\frac{I}{N} \sin \frac{\pi}{N}\left(k-\frac{1}{2}\right)
$$

ただし, 計算の便宜上, $\beta r$ は $I / N$ と置換した $(I, N$ はそれぞ れ電流強度を表す任意定数と導体ぺア数である).

このとき, $x$ 軸上の点 $\mathrm{P}$ おいて, 全導体による総合磁界 $H(x)$ は次式のようになる.

$$
H(x)=\frac{I r}{\pi N} \sum_{k=1}^{N} \frac{\sin ^{2} \theta_{k}}{r^{2}+x^{2}-2 r x \cos \theta_{k}}
$$

上式に基づき，磁界の計算を行った結果を Fig. 5 に示す。こ こでは $I=r=1$ とした。この図より, 導体ペア数 $N$ が 3 の とき, 導体に囲まれた部分における磁界均一性が大きく改善し ているため, 長方形コイル数は 3 を採用する。.また, 式 (6) よ り, 長方形コイル $1,2,3$ の電流強度の比はそれぞれ $1: 2: 1$ と する.

次に, 長方形コイルの短辺部分を考慮した場合, 磁界の均一 性が確保される長方形コイルの寸法比を得るために，Fig. 6(a) に示した計算領域を定義し，ビオ・サバールの法則により磁界 の計算を行った。評価指標としては，次式で表される磁界均一 性 $\varepsilon$ を用いた。

$$
\varepsilon=\frac{\sqrt{\left(B_{x}-B_{0 x}\right)^{2}+B_{y}^{2}+B_{z}^{2}}}{B_{0}} \times 100(\%)
$$

ここで， $B_{0}$ は計算領域中央における磁界強度である. Fig. 7 は長方形コイルの高さ $h$ と幅 $w$ の比 $(h / w)$ を変化させた場合 の磁界均一性 $\varepsilon$ の計算領域内での最大值を示す。この図より, $h / w$ が 2 より大きいとき, 磁界均一性 $\varepsilon$ の最大值はほぼ一定值 となっているため, 長方形コイル寸法比 $h / w$ は 2 を採用する.

式 (5) を近似的に満たす電流分布は, Fig. 6(b) に示す 2 個の 円形コイルにより発生させる。 円形コイル 1,2 の電流強度の 比は同じで，電流の方向はそれぞれ反対とする.

磁界傾斜が最も大きくなる円形コイルの寸法比を得るため に, Fig. 6(b) に示した計算領域を定義し, 磁界の計算を行っ た. Fig. 8 は円形コイルの間隔 $d_{c}$ と直径 $d$ の比 $\left(d_{c} / d\right)$ を変化 させた場合の磁界傾斜 $\left(d B_{x} / d x\right)$ の計算領域内での最小值を示 す.この図より, $d_{c} / d$ が 1.1 から 1.4 程度のとき, 磁界傾斜の 最小值は最も大きくなるため, 円形コイル寸法比 $d_{c} / d$ は 1.1 を採用する。

実際に作製したコイルの寸法と巻線ターン数を Table 1, 円 形コイル中間部 $x y$ 平面上における $x$ 方向磁界の計算值を Fig. 9, 計算值と测定值の比較を Fig. 10 に示す（長方形コイル 1,3 の励磁電流 $\left(I_{r 1}, I_{r 3}\right)$ は $1.5 \mathrm{~A}$, 長方形コイル 2 と円形コイル 1 ,

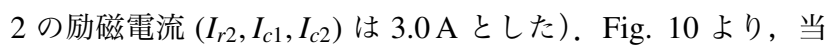
初の目標である Fig. 3(c) に示された特性を持った傾斜磁界が 発生できていることが確認される.コイル中心 $(x=y=z=0)$ において計算值では $B_{x}=8.2 \mathrm{mT}, d B_{x} / d x=0.85 \mathrm{~T} / \mathrm{m}$, 測定值 では $B_{x}=6.8 \mathrm{mT}, d B_{x} / d x=0.65 \mathrm{~T} / \mathrm{m}$ であり, この差が生じた 原因としてはコイル製作時の占積率の低下が考えられる. 結果 として磁性物に働く磁力も小さくなるが, 分離容器の設計にお いてはその点を考慮した。 


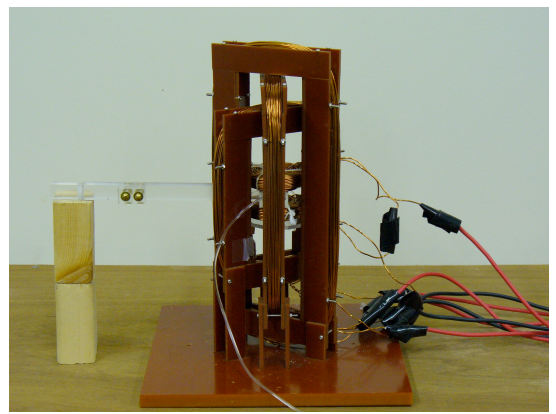

Fig. 11 Magnetic separator for preliminary experiment.

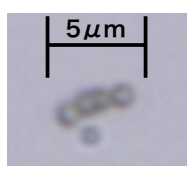

Fig. 12 Micrograph of magnetic beads SPHERO CM-10.

また, 磁界中で磁気ビーズに㗢く磁力 $\boldsymbol{F}$ は次式のように与 えられる7).

$$
\boldsymbol{F}=\left(1-N_{d}\right) \mu_{0} \mu_{r} V_{m}(\boldsymbol{H} \cdot \nabla) \boldsymbol{H}
$$

ここで, $N_{d}, \mu_{0}, \mu_{r}, V_{m}, \boldsymbol{H}$ はそれぞれ反磁界係数, 真空中の透磁 率, 磁気ビーズの比透磁率, 磁気ビーズの体積, 磁気ビーズの 周囲の磁界である. 反磁界係数 $N_{d}$ は, 球状のビーズでは 0.33 である。この磁力による磁性物の移動速度 $\boldsymbol{v}_{m}$ は次式のように なる。

$$
\boldsymbol{v}_{m}=N \boldsymbol{F} / 3 \pi \eta D_{p}
$$

ここで, $N, \eta, D_{p}$ はそれぞれ 1 個の分離対象物に結合した磁気 ビーズの個数, 液体粘度, 分離対象物の直径である.

磁気ビーズ 1 個 (直径 $1.2 \mu \mathrm{m}$, 比透磁率 11.3 , 密度 $1580 \mathrm{~kg} / \mathrm{m}^{3}$ ) に同程度の直径の分離対象物 1 個を結合させ，水 中 (粘度 $0.89 \mathrm{mPs} \cdot \mathrm{s}$ ) で試作したコイルの中心に置いた場合, 磁気ビーズの周囲の $x$ 方向磁界は $6.8 \mathrm{mT}, x$ 方向磁界傾斜は $0.65 \mathrm{~T} / \mathrm{m}$ となり, 式 (9), (10) より磁気ビーズの $x$ 方向磁力は $2.4^{-14} \mathrm{~N}, x$ 方向速度は $2.4 \mu \mathrm{m} / \mathrm{s}$ であることが求められる.

\section{2 分離容器の寸法の検討}

分離容器の寸法 (長さ $l$, 高さ $h$, 幅 $w$ ) を定めるにあたり, 高 分離率を達成するため, 磁気ビーズと分離対象物の分離容器内 滞留時間 $T_{r}$ に関して，以下の条件を満たすようにする。

$$
T_{m}<T_{r}<T_{s}
$$

ここで, $T_{m}$ は磁気ビーズと分離対象物の分離容器内での分離 所要時間， $T_{s}$ は沈殿時間である.

Inlet から容器内に入った磁性物が Positive selection から出 るようになるためには, 少なくとも $w / 2$ 以上の $x$ 軸正方向へ の移動が必要であることから， $T_{m}$ は $w / 2 v_{m}$ となる（ $v_{m}$ は磁力 による磁性物の $x$ 方向移動速度). また, $T_{r}$ は $l / v_{f}, T_{s}$ は $h / v_{s}$ となる（ $v_{f}$ は $y$ 軸正方向の液体の流速， $v_{s}$ は重力による磁性 物の $z$ 軸負方向の沈殿速度). 以上より, 式 (11) は以下のよう になる.

$$
v_{s} l / h<v_{f}<2 v_{m} l / w
$$

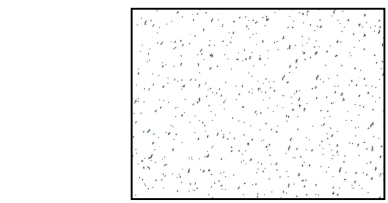

(a) Before separation

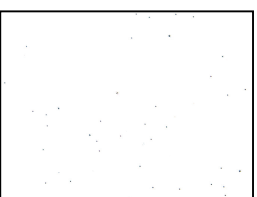

(b) After separation (Negative selection)

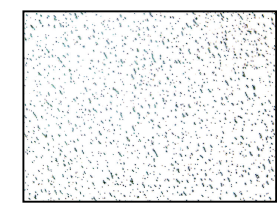

(c) After separation (Positive selection)

Fig. 13 Micrographs of magnetic beads for three situations.

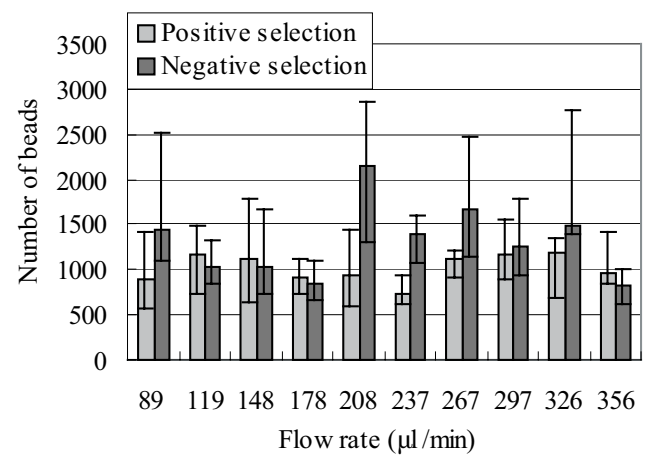

(a) Without magnetic field.

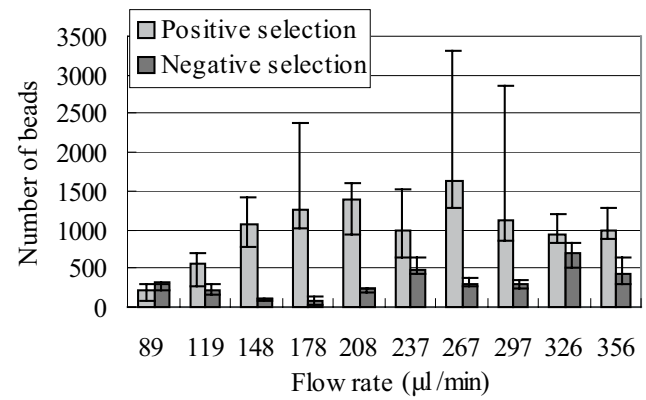

(b) With magnetic field.

Fig. 14 Number of magnetic beads counted from micrographs

上式で, 磁気ビーズの沈殿速度 $v_{s}$ は次式のように与えられ $3^{8)}$.

$$
v_{s}=\left(\rho_{b}-\rho_{f}\right) g D_{p}^{2} / 18 \eta
$$

ここで, $\rho_{b}, \rho_{f}, g$ は，それぞれ磁気ビーズの密度，液体の密度， 重力加速度である.

分離容器の長さ $l$, 高さ $h$, 幅 $w$ はそれぞれ $25 \mathrm{~mm}, 10 \mathrm{~mm}$, $10 \mathrm{~mm}$ とし, 前述の磁性物の速度 $v_{m}$ と沈殿速度 $v_{s}$ を式 (12) に代入すると, 次式の流速 $v_{f}$ の範囲で分離が行われることが わかる。

$$
1.28 \times 10^{-6}<v_{f}(\mathrm{~m} / \mathrm{s})<1.20 \times 10^{-5}
$$




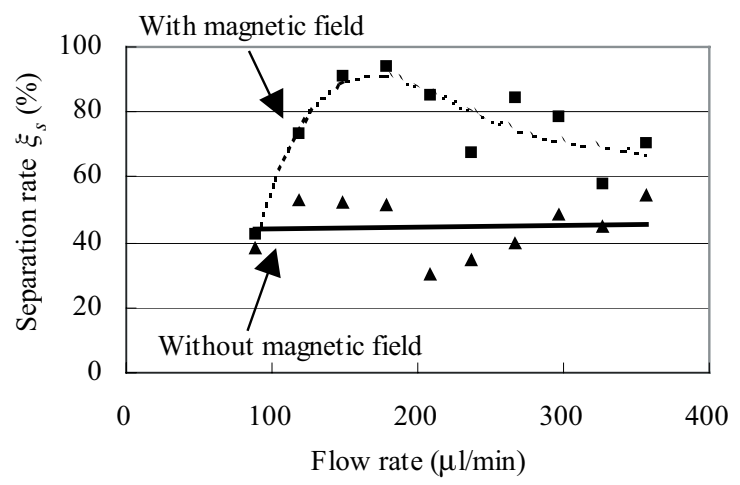

Fig. 15 Separation rate for all flow rates.

\section{4 磁気ビーズによる予備分離実験}

\section{1 装置構成と手順}

Fig. 11 に試作した分離装置の外観写真を示す。磁気ビーズ による予備分離実験は Fig. 1 の装置構成を用い, 長方形コイル 1,3 の励磁電流 $\left(I_{r 1}, I_{r 3}\right)$ は $1.5 \mathrm{~A}$, 長方形コイル 2 と円形コイル

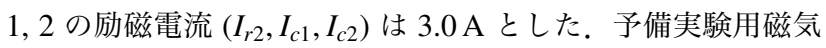
ビーズとしては, SPHERO CM-10(Fig. 12) を超純水で 20 倍希 釈したものを使用した。分離実験後は, Positive 及び Negative selection から得られた磁気ビーズ含有液体を顕微鏡 (倍率：200 倍) で 6 枚撮影し, 画像鮮明化処理を行い, 画像処理ソフトウ エアWinROOFで画像中の磁気ビーズ個数を数えた.

\section{2 予備実験結果}

Fig. 13 にポンプの流量が $178 \mu \mathrm{l} / \mathrm{min}$ のきの分離前後の磁 気ビーズ画像 (鮮明化処理後) を示す。この図より, 分離処理 後は Positive selection から多数の磁気ビーズが取り出されてい ることが容易にわかる。 また, Fig. 14 に示す各流速ごとの画 像中の磁気ビーズ個数からは, 磁界非印加時は両取出口から同 様に磁気ビーズが得られ, 磁界印加時は Positive selection から 多数の磁気ビーズが得られていることがわかる

分離率 $\xi_{s}$ として, 次式のように定義すると, 各流速におけ る分離率は Fig. 15 のようになる.

$$
\xi_{s}=\frac{N_{p}}{N_{p}+N_{n}} \times 100(\%)
$$

ここで, $N_{p}, N_{n}$ はそれぞれ Positive 及び Negative selection での磁気ビーズ個数である. Fig. 15 より, 流量が $178 \mu \mathrm{l} / \mathrm{min}$ のとき分離率が最大である.
これより流量が小さい領域で分離率が低くなっているのは, 磁気ビーズが容器内の磁界に捕捉されてしまうこと, および沈 殿によりビーズが容器底部に達してしまい液流に流されにくく なったことが原因であると考えられる，一方，流量が大きい領 域でも分離率の低下がみられるのは，分離時間が短すぎるため に十分に Positive selection 側に磁気ビーズが移動しないためで あると考えられる.

また，分離率最大のときの流量 $(178 \mu \mathrm{l} / \mathrm{min})$ は前節における 最大設計流量 $\left(1.2 \times 10^{-9} \mathrm{~m}^{3} / \mathrm{s}=72 \mu \mathrm{l} / \mathrm{min}\right)$ よりも大きい值で ある. その理由としては, 磁気ビーズがクラスター状の固まり になったことで, 当初の計算した沈殿速度よりも磁気ビーズが 早く沈殿したことが一因として考えられる.

\section{5 結論}

本稿では, 他の従来の連続処理型分離装置に比べて高スルー プットの分離装置の構造を提案し, コイル及び分離容器の設 計・試作を行った。また, 磁気ビーズを用いた分離実験の結 果, 流量が $178 \mu \mathrm{l} / \mathrm{min}$ のときに分離率 $94.4 \%$ が得られた。し かし，より実際的な使用に近い条件に近づけるために，磁性物 と非磁性物が混在した液体からの磁性物の分離実験を行う必 要がある。ただし, 現状の装置では非磁性物は分離容器の双方 の出口から等しく得られることになるため, 磁性物の純度が 高くなるよう分離容器の改良・装置の多段化等を行わねばなら ない.

以上を踏まえ, 今後はより高純度の分離を目指し装置を改良 し，より実際の使用に近い対象物を使って実験を行う予定で ある。

\section{References}

1) I. Šafařík and M. Šafaříková: J. Chromatography B, 722, 33 (1999).

2) NEDO: FOCUS NEDO, 17, 9 (2004).

3) R. Hartig, M. Hausmann, G. Lüers, M. Kraus, G. Weber, and C. Cremer: Rev. Sci. Instrum., 66, 3289 (1995).

4) H. Inokuchi, Y. Suzuki, N. Kasagi, N. Shikazono, K. Furukawa, and T. Ushida: Proc. the 22nd sensor symp., Tokyo, 2005, IEEJ Sensors and Micromachines Soc., 125 (2005).

5) R. Rong, J. Choi, and C. H. Ahn: Proc. the 16th IEEE MEMS Workshop, 530 (2003).

6) Glover P.: 6th Int. Conf. on Magn. Resonance Microscopy, http:// www.magres.nottingham.ac.uk/conferences/2001/icmrm/ ICMRMglover.ppt (As of March 19, 2007)

7) H. Suzuki: Doctoral Thesis, Dept. Mech. Eng., The University of Tokyo., http://www.hybrid.iis.u-tokyo.ac.jp/hsuzuki/docs/ hsuzuki_dissertation.pdf (As of March 19, 2007).

8) J. Tsubaki, M. Suzuki, and Y. Kanda: Nyumon Ryushi Funtai Kogaku (in Japanese), p. 92 (Nikkan Kogyo Shimbunsya, Tokyo, 2002).

2006 年 10 月 5 日受理, 2007 年 3 月 19 日採録 